\title{
(Confessional) Lutheran perspectives on the unity of the church
}

\begin{tabular}{|c|c|}
\hline $\begin{array}{l}\text { Author: } \\
\text { Dieter H. Rein }\end{array}$ & torf ${ }^{1,2}$ \\
\hline $\begin{array}{l}\text { Affiliations: } \\
{ }^{1} \text { Evangelical LI } \\
\text { Immanuel Cor } \\
\text { Free Evangeli } \\
\text { Synod (FELSIS }\end{array}$ & $\begin{array}{l}\text { theran } \\
\text { gregation, } \\
\text { al Lutheran } \\
\text { d), South Africa }\end{array}$ \\
\hline $\begin{array}{l}{ }^{2} \text { Faculty of Th } \\
\text { University of } \\
\text { South Africa }\end{array}$ & $\begin{array}{l}\text { ology, } \\
\text { retoria, }\end{array}$ \\
\hline $\begin{array}{l}\text { Research Proje } \\
\text { Project Leade } \\
\text { Aarde (1) } \\
\text { Project Numb }\end{array}$ & $\begin{array}{l}\text { ct Registration: } \\
\text { : A.G. van } \\
\text { er: } 2334682\end{array}$ \\
\hline $\begin{array}{l}\text { Description: } \\
\text { Dr Reinstorf is } \\
\text { the research } \\
\text { Theology and } \\
\text { directed by Pr } \\
\text { van Aarde, Po } \\
\text { Professor in th } \\
\text { at the Faculty } \\
\text { the University }\end{array}$ & $\begin{array}{l}\text { participating in } \\
\text { roject, 'Biblical } \\
\text { Hermeneutics', } \\
\text { of. Dr Andries } \\
\text { t Retirement } \\
\text { e Dean's Office } \\
\text { of Theology of } \\
\text { of Pretoria. }\end{array}$ \\
\hline $\begin{array}{l}\text { Correspondin } \\
\text { Dieter Reinsto } \\
\text { dieter.reinstor }\end{array}$ & $\begin{array}{l}\text { author: } \\
\text { rf, } \\
\text { f@gmail.com }\end{array}$ \\
\hline $\begin{array}{l}\text { Dates: } \\
\text { Received: } 19 \text { J } \\
\text { Accepted: } 05 \\
\text { Published: } 31\end{array}$ & $\begin{array}{l}\text { une } 2017 \\
\text { uly } 2017 \\
\text { Aug. } 2017\end{array}$ \\
\hline $\begin{array}{l}\text { How to cite th } \\
\text { Reinstorf, D.H. } \\
\text { '(Confessional } \\
\text { perspectives o } \\
\text { the church', H } \\
\text { Studies/Theol } \\
73(1) \text {, a } 4708 \text {. } \\
\text { org/10.4102/ }\end{array}$ & $\begin{array}{l}\text { is article: } \\
\text { 2017, } \\
\text { Lutheran } \\
\text { n the unity of } \\
\text { TS Teologiese } \\
\text { gical Studies } \\
\text { tttps://doi. } \\
\text { ts.v73i1.4708 }\end{array}$ \\
\hline $\begin{array}{l}\text { Copyright: } \\
\text { (c) 2017. The A } \\
\text { Licensee: AOSI } \\
\text { is licensed und } \\
\text { Creative Comn } \\
\text { Attribution Lic }\end{array}$ & $\begin{array}{l}\text { uthors. } \\
\text { S. This work } \\
\text { ler the } \\
\text { nons } \\
\text { ense. }\end{array}$ \\
\hline Read online: & \\
\hline 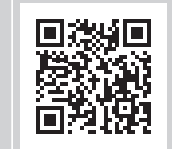 & $\begin{array}{l}\text { Scan this QR } \\
\text { code with your } \\
\text { smart phone or } \\
\text { mobile device } \\
\text { to read online. }\end{array}$ \\
\hline
\end{tabular}

From personal experience, this article shares to what degree the Faculty of Theology at the University of Pretoria was and continues to be a gateway to the future, challenging among others the divisions that characterise the Church of Christ worldwide. The article argues that for the 16th-century Reformers the unity of the church was a given and that the (Lutheran) confessions were written to establish such a unity through agreement in confession and joint rejection of false doctrines. However, such statements of faith did not overcome the divisions, but institutionalised them, leading to a divided Church of Christ. Political intervention to work unity between Lutherans and Reformers deepened divisions more than ever, leading among others to a break of fellowship at the Lord's Supper. Applying Luther's hermeneutical principle of was Christum treibet (what drives Christ), the author seeks to rediscover a way of interpreting Scripture by focusing not on literal differences, but on that which is foundational to Scripture, namely the Christ event. This is applied in particular to the topic of table fellowship and divisions in Corinth with regard to the Lord's Supper, addressed in 1 Corinthians 11, culminating in a critical deconstruction of past practices in confessional Lutheran churches. In view of doctrinal differences, a hermeneutics of conversation is proposed that can vigorously debate differences of understanding, without threatening the unity that is worked by Christ himself.

\section{A Reformed professor and a Lutheran pastor}

Was it a coincidence or God's providence when in 1992 I knocked on the office door of Professor Andries van Aarde of the Faculty of Theology at the University of Pretoria. The reason for my visit was that I had been tasked by the Synodical Council of the Free Evangelical Lutheran Synod in South Africa (FELSISA) to engage in further studies. It was part of a succession plan to eventually replace one of the two pastors who lectured at the Lutheran Theological Seminary in Pretoria, a private and unaccredited theological institution of the FELSISA. The choice to study New Testament was not mine, but that of the church leadership. On asking what I wished to research, I could provide no answer. Van Aarde must have been flabbergasted about this potential new Master's student, whose theological qualifications strictly speaking did not even meet the requirements for enrolment, apart from a BA (Hons) degree in Greek obtained from the University of Pretoria in 1982. But then again, the pastor did not realise what a theologically controversial and academically astute figure was sitting in front of him either.

The years that followed were rewarding and tumultuous at the same time. On the side of the pastor there was, on the one hand, a high appreciation for the vast amount of knowledge the professor internalised accompanied by a sincere dedication and love for his church. On the other hand, however, there was confusion resulting from his critical approach to Scripture at a time when the pastor had not engaged in any form of historical critical research. The resulting Anfechtungen were at times almost unbearable, with van Aarde sounding a pastoral warning: 'If you close the door on doubt, it will creep through the back window'. If I wished to obtain my degree at this institution, I had no choice but to confront my doubts head on, long before the meaning of Martin Luther's words on what makes a good theologian dawned on me. In his table talk from 1532 we read:

I did not learn my theology all at once, but had to search constantly deeper and deeper for it. My temptations did that for me, for no one can understand Holy Scripture without practice and temptations. (Luther's Works 1966:34:285) ${ }^{1}$

These words reflect a conscious shift in Luther's thinking that theologians are not just made in monasteries or even classrooms, ascending the ladder of mediation and prayer that would eventually culminate in 'contemplation' (the experience of ecstasy, bliss, rapture and illumination

1.For an extensive exposition of Luther's spirituality, see inter alia Kleinig (2002:255-266). 
through union with the glorified Christ), but in everyday life where prayer and meditation inevitably lead to temptation, inviting further prayer and more intensified meditation.

Thus started the unlikely journey of a Reformed professor and a Lutheran pastor at a time when the faculty of theology at the University of Pretoria still consisted of two sections associated with two different Reformed churches. Since then times have changed. The faculty has indeed become radically inclusive, welcoming to all, including the newly established Lutheran Theological Seminary of Tshwane. As such, it has become a gateway to the world, in constant dialogue with other institutions of learning that impact the church and society, both locally and abroad.

It is this inclusiveness that challenges our conventional understanding of church unity and church fellowship. It is a topic that should not be confined to the classroom as it plays itself out in everyday life, affects the lives of individuals and impacts the testimony of the church to the world. I wish to proceed by providing a very broad overview of the unity of the church as understood by the 16th-century Reformers, the formation of the 'free' Evangelical Lutheran Churches and the way history shaped its confessional Lutheran identity, followed by some challenges regarding the way it practices church fellowship, in particular relating to the celebration of the Lord's Supper. The latter can be seen as an example of deconstructing the past and probably the first steps towards a future that reflects the unity worked by Christ's mercy.

\section{The Reformers and church unity}

For Martin Luther, and the other Reformers, the unity of the church was a given. As such they gathered in Augsburg not with the intent to break away from the Roman Catholic Church, but rather to make every effort to keep the unity that is worked by the Spirit (Eph 3:4). In the preface to the Augsburg Confession (AC), the fervent hope is expressed that matters understood differently:

may be settled and brought back to one simple truth and Christian concord ... [so that] we may embrace and maintain the future of one pure and true religion under one Christ, doing battle under Him [Psalm 28:8], living in unity and concord in the one Christian Church. (Concordia 2005:27)

The source for their hope and desire was that there is in fact only 'one holy, catholic, and apostolic church' on Earth (Nicene Creed), the communion of all saints (Apostle's Creed), with Christ Jesus himself being the cornerstone (Eph 2:20). This is well captured in their definition of the Church in the AC, article VII:

Our churches teach that one holy Christian Church is to remain forever. The Church is the congregation of saints [Psalm 149:1] in which the Gospel is purely taught and the Sacraments are correctly administered. For the true unity of the Church it is enough to agree about the doctrine of the Gospel and the administration of the Sacraments. It is not necessary that human traditions, that is, rites or ceremonies instituted by men, should be the same everywhere as Paul says, 'One Lord, one faith, one baptism, one God and Father of all' (Eph 14:5-6). (Concordia 2005:34)

The unity of the church is therefore not the goal, but rather the presupposition that compelled the Reformers to present their teachings at Augsburg in the hope that the given unity would be established (and become visible) through agreement in confession and joint rejection of false doctrines that contradict the apostle's teachings (cf. Nafzger 2007:62-63).

History records that such unity was not established with the Roman Catholic Church, or with Ulrich Zwingli and his colleagues, or with the Anabaptists. The 'one holy, catholic, and apostolic church', which is believed, experienced a visible division.

This disturbing event also prompted political involvement, not only in Augsburg but also in Marburg in 1529 (cf. Heussi 1981:298). This colloquy was attended by Martin Luther and Ulrich Zwingli (and their colleagues) at the behest of elector Philipp I of Hessen in the hope that protestant differences could be overcome so as to present a united front in an ever deepening division with the Roman Catholic Church that threatened the very existence of the Protestants. For the elector it was essential that the two churches unite. Although agreement was reached on 14 theological points, there was no such agreement with regard to the Lord's Supper, the dispute ending with Luther refusing altar fellowship to Zwingli. ${ }^{2}$

By 1577 all efforts to overcome the divisions had largely dissipated. On the Lutheran side, the authors of the Formula of Concord, firmly resisted any unity that can be regarded as a papering over of differences, which would simply give the appearance of unity (FC SD XII,5-6; Concordia 2005:616). Instead they expressed their clear intent not to yield in:

any part of God's eternal, immutable truth for the sake of temporal peace, tranquility, and ... [external] unity. Such peace and unity would have no permanence, since it is devised against the truth and for its suppression. (FC SD XI,95-96; Concordia 2005:615)

Although the Lutheran Reformers continued to reject any form of condemnation based on differences in ceremonies, they stressed more than ever that a prerequisite for establishing church unity is agreement in 'all doctrines of faith' and 'also the right use of the sacraments' (FC SD X,32; Concordia 2005:602). Lines were firmly drawn.

\section{The Union Movement and the formation of the Free Evangelical Lutheran Churches ${ }^{3}$}

Similar to the Marburg Colloquy, the Union Movement of the 19th century can be described as a royal attempt to merge

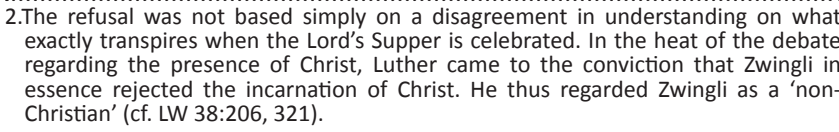

2.The refusal was not based simply on a disagreement in understanding on what exactly transpires when the Lord's supper is celebrated. In the heat of the debate regarding the presence of Christ, Luther came to the conviction that Zwingli in Christian' (cf. LW 38:206, 321)

3.This overview relies primarily on Horwitz, C. 1964. 
Lutherans and Calvinists. The movement was largely triggered in 1613 when the elector of Brandenburg, Johann Sigismund, converted from the Lutheran to the Reformed faith, possibly motivated by his intentions to combat the threats from Rome better. Failing to convince his citizens to join him, he embarked on uniting the churches among others by abolishing the AC (of 1520) and the Formula of Concord (1580) from the confessional writings of the Church.

However, the union movement only gained real momentum under King Frederick William III, who ascended the throne of Prussia in 1798. He lived in a denominationally mixed marriage, which prevented him to celebrate the Lord's Supper with his Lutheran wife, Queen Louise. The many attempts to unite the churches culminated in the preparation of a united service book. On 27 September 1817, Frederick William announced that on the 300th anniversary of the Reformation Potsdam's Reformed court and garrison congregation and the Lutheran garrison congregation would unite into one 'evangelical' Christian congregation on Reformation Day, 31 October. Thereafter, the king expressed his wish that all Protestant congregations would follow his example. In 1821 the new service book was completed and introduced in the military. When the king attempted to introduce the service book in the rest of Prussia, he received opposition from various courters, also from Friedrich Schleiemarcher who questioned the authority of the king to mingle in matters of the church (cf. Horwitz 1964:22-31).

In 1829 Frederick William III ordered all Protestant congregations and clergy in Prussia to give up the names 'Lutheran' and 'Reformed' and take up the name 'Evangelical'. The decree was to be a name change only and not to be construed as an enforced change of belief or denomination. In April 1930 the king ordered that all Protestant congregations celebrate the Lord's Supper using the new agenda. However, rather than having a unifying effect, the king's decree created a great deal of dissent among some Lutherans. In subsequent years, pastors who resisted accepting the new agenda were forced to relinquish the office of the ministry and both clergy and laity were barred from participating in the sacraments. This led to the formation of Free Evangelical Lutheran Churches in Germany, with the word 'free' indicating its independence from the state churches. Many so-called 'confessional' Lutherans immigrated to other countries. FELSISA, the church into which I was born (and socialised), has its roots in the Free Evangelical Lutheran Church in Hannover.

As in the Reformation period, the further division of the Church led to the renewed need to (re)define one's own identity. Among the 'free' churches, today referred to primarily as the 'confessional Lutherans', this identity is deeply rooted in upholding the Lutheran Confessions as a faithful expression of Scripture, in particular with regard to the Lord's Supper. ${ }^{4}$

4.Confessional Lutherans accept the doctrines taught in the Lutheran Confessions (including the Book of Concord of 1580) in their entirety because (quia) they are (including the Book of Concord of 1580) in their entirety because (quia) they are complete faithful to the teaching of Scripture, to be distinguished from those who accept them only insofar as (quatenus) they are in accordance with Scripture. The former resist reductionism, whereas the latter wish to distinguish more clearly between Scripture as the norma normans and the confessions as the norma normata.
Among confessional Lutherans the endeavour to define its identity has largely culminated in the statement, 'Church fellowship is altar fellowship (and vice versa)'. In short, it means that although the Church's spiritual unity is a given, external fellowship is established by agreeing in all doctrines of faith. This god-pleasing fellowship is then celebrated in the joint participation of the Lord's Supper. Conversely, those who belong to a church with whom church fellowship has not been established are barred from attending the Lord's Supper with exceptions made only in cases of (extreme) pastoral care. ${ }^{5}$ This action is seen as a 'necessary' step as all false teachers are to be avoided in order to safeguard the true teaching of the Gospel. ${ }^{6}$ From a confessional Lutheran perspective, including the FELSISA, this has been the status quo since the 16th century. ${ }^{7}$ Ironically, there has been a reversal of roles. Persecuted Lutherans in the 19th century, barred from holding the office of the ministry and participating in the sacraments, now exclude others from the Lord's Supper.

\section{Overcoming divisions at the Lord's Supper}

The space is not given to explore the wide range of topics associated with church unity and disunity. My focus falls on one topic only: The division at the Lord's Supper. I focus on this topic as little affects the laity more. Families whose children have married into other churches have been torn apart.

One would have expected the tenet sola Scriptura to be a uniting factor among the churches of the Reformation. That this is not the case is well argued by Dreyer et al. (2013). Different hermeneutical approaches, confessional traditions and cultural contexts lead to different conclusions, despite adhering to Scripture as the primary authority. Conceptions of Scripture also differ. For some (also confessional Lutherans), sola Scriptura implies tota Scriptura based on a

5.See The Lutheran Understanding of Church Fellowship, Study Materials prepared by the President of the Synod and the Commission on Theology and Church Relationships, adopted by the Synodical Convention of the Lutheran Church Missouri Synod (LCMS) in 2001, which states: 'While the church's internal unity is perfect and known only to God (Eph 1:4), the limits of external fellowship are determined by whether the Gospel is preached purely and the sacraments are administered according to Christ's institution. The Gospel and the sacraments are in themselves always pure. In this way they create and preserve the church in der hidden unity throughout the world. Yet, when church bodies make public confessions of the Gospel and the sacraments, tragically some obscure or explicitly contradict the teaching of the Gospel and proper administration of the sacraments. For this reason the limit or boundaries of external fellowship are sacraments. For this reason the limit or boundaries of external fellowship are creeds and confessions. Churches in alter and pulpit fellowship share the same confession, including the rejection of errors that contradict this confession. Where churches cannot agree on a common confession, the basis for church fellowship does not
exist' (quoted by Nafzger 2007:68).

6.With reference, among other, to Romans 16:17, Galatians 1:6-9, 4:30, 5:9.

7.On the European continent the Leuenberg Agreement (LA) of 1973 can be seen as one attempt among many to overcome the status quo. In the LA doctrinal consensus is no longer seen as a prerequisite of unity and church fellowship. The focus is on the 'core principles' of the Gospel message (i.e. its 'foundation' [Grund], (LA, 1). A common understanding of these core principles coupled by the dedication and commitment to move forward in service and worship, common witness and theological reflection and clarification suffice to declare church fellowship, here understood as a 'community' of churches. Within this community of churches altar understood as a "community' of churches. Within this community of churches altar and pulpit fellowship are reciprocated. Theological differences are regarded as diverse expressions [Ausdruck] of the same truth. It represents 'unity in diversity. Confessional Lutherans have rejected the LA as a papering over of doctrina differences, akin to the Union Movement, asserting that truthfulness and falsehood are nevertheless articulated by teaching, with the distinction between Grund und Ausdruck failing to address erroneous teachings within the church (see inter alia Assendorf \& Künneth 1974; Klän \& Da Silva 2012). 
verbal inspiration of Scripture, which leaves no space for diverging passages and interpretations.

My own research has led to a renewed look into Luther's principle was Christum treibet. The research efforts revealed a lack of sources, in particular among confessional Lutheran scholars, despite the fact that this principle speaks directly to the use and authority of Scripture. Surprisingly, the one article found was authored by my Reformed companion, van Aarde (2001:148-171). Facing criticism that in his search for the historical Jesus he has abandoned the basis of the canon as the primary authority of Scripture, he is largely responsible for introducing the the cause of Jesus as the canon behind the canon' into the scholarly debate in South Africa. His efforts are not to be confused with searching for a canon-within-the-canon (Alexander Schweitzer), widely rejected by confessional Lutherans as a form of reductionism. It is a search for what is foundational to the authority of the canon.

Being a critical historical scholar Van Aarde distinguishes between the authentic words and deeds of Jesus and the faith assertions of his followers. Although both make up the kerygma, which forms the basis of our faith to live by the cause of Jesus, the assertions of faith (both in the canonical and postcanonical period) do not equally convey the cause of Jesus and should not become the object of faith. Failure to make this distinction can lead to forms of oppression and alienation, when those in power exercise authority over those less knowledgeable. This was the case in the period following the canonisation of the Hebrew Scriptures. Scribes influenced the illiterate lower classes by setting up schools in order to interpret these sacred texts within an ideology that constituted a frame of reference among the masses that agreed with their own symbolic and social world (cf. Van Aarde 2001:163). This led to a number of purity regulations that barred sinners from entering the temple and prohibited the righteous Israelites to have table fellowship with known sinners.

Van Aarde (2001:155) asserts that it was none other than Martin Luther himself who taught us to scrutinise the traditions, not only of the church but also of the apostolic witnesses within Scripture itself. The touchstone for evaluating all books is what preaches and drives Christ home (was Christum treibet). From Luther's preface to the letters of Saint James and Jude, it is evident that adhering to the 'apostle's teaching', so central to the reformers (and their understanding of sola Scriptura), was not to be understood literally, but materially. He writes:

Whatever does not teach Christ is not apostolic, even if Saint Peter or Saint Paul teaches it. Once again whatever preaches Christ, that is apostolic, even if it were to be presented by Judas, Annas, Pilate, and Herod. (LW 35:36)

The examples provided by Luther are subversive to the extreme, but confirm his deep conviction that the Christ event is foundational to Scripture. That faith assertions within Scripture may differ was well tolerated by Luther.
Problematic for him was that certain faith assertions (in the context in which they were read) could cause alienation from the cause of Jesus. If from Luther's perspective that was the case, he did not hesitate to evaluate such assertions critically, epitomised by his assessment of James as an 'epistle of straw' (LW 42:7-14). ${ }^{8}$ One can conclude that for Luther was Christum treibet was the sadis est [it is enough] for church unity (AC VII) (Concordia 2005:34).

My exploration of this principle is not to culminate into an exposition of the central topic of justification in Paul's letters to the Romans and Galatians that shaped Martin Luther's theology, but to explore the 'heart' of Christ (as that which drives Christ) in relationship to table fellowship. By doing so, Christ is not the object of reflection but rather the subject, leading to the question: What drove Christ and made his heart throb to cross traditional boundaries of table fellowship? ${ }^{9}$

Again space is not given for an extensive exploration. Practicing table fellowship in ancient Israel gave expression to a particular understanding of God's holiness as 'creating order' by making a clear distinction between what is holy and profane, clean and unclean (cf. Neyrey 1991:271-304). ${ }^{10}$ Endeavouring to be holy as God himself is holy ( $\mathrm{Lv} 11: 4-45$, 19:2, 20:7, 26, 21:28), no Israelite would share table fellowship with 'tax collectors and sinners'. However, this boundary is repeatedly crossed by Jesus based on a reinterpretation of God's holiness in terms of God's compassion (Lk 6:36). It is in particular in Luke's Gospel that God's compassion and mercy is portrayed as his central attribute, with the tone being set in both the Magnificat and the Benedictus (see 1:50, $54,47,72,78)$. It is this 'heart' of Christ that lies at the core of a number of meal scenes in Luke's Gospel that culminate in the Lord's Supper (Lk 5:27-6:5, 7:36-50, 9:10-17, 10:38-42, 11:37-54, 14:1-24, 15,1-32, 16-31, 19,1-10, 22,7-38, 24:28-35, 24:41-43) (see Heil 1990). These meals scenes highlight God's forgiveness, his generosity, his radical inclusiveness (all are invited). Inevitably, the meals scenes remain open-ended, inviting the reader/listener to become part of God's new household and join in the feast.

Against the backdrop of not being able to confess what they believed and being persecuted for it, confessional Lutherans have placed a high emphasis on understanding the Lord's Supper correctly in order to preserve the pure teachings of the Gospel. Determinative for its church polity and everyday practice is Paul's engagement with his congregation in 1

8.LW 42:7-14. Maurer (1970:152) counters the idea that Luther therefore no longer adhered to all books of the canon. He writes: 'Das [was Christum treibet] bedeutet nicht Aufhebung des Kanons, auch nicht Überschreitung des Kanons, sondern Auslegung des Kanons im Licht der Christusoffernbarung mit der damit gegebenen Geistesverheißung.' Luther's assessment of Saint James was also not absolute or static. He assumed that it might speak differently to others in a different time and context. This is further underlined by Thomson (2005:133), who emphasises that Luther's assessment of the Epistle of James was a 'comparative assessment' (compared to all others) and that by 1516 his own assessment of the letter had also undergone some change.

9.Such a reading is validated by Luther's recurring statements on seeing God's 'heart' in the suffering and resurrection of Christ, most prevalent in A Meditation of Christ's Passion (LW 42:7-14). In contrast to others who see Christ as the 'face' of God, Luther sees him primarily as the 'heart' of God.

10.For maps of holiness, see Neyrey (1991:278-279) as well as Malina (2003:149-183). 
Corinthians 10 and 11. The pivotal point is the interpretation of 1 Corinthians 11:29. Does the term body (soma) in this verse refer to the 'sacramental' body of Christ received in the Lord's Supper or the 'church' as the body of Christ? Should it indeed refer to the sacramental body, then - from a confessional Lutheran perspective - the discernment that needs to take place to avoid judgement is, in the first place, the objective reality of Christ in the sacrament, which then necessitates a meal in social cohesion among the believers partaking of the meal. The failure to confess the objective presence of Christ is declared to be unscriptural, a false teaching, which makes a break in table fellowship necessary. ${ }^{11}$

1 Corinthians 11 remains a matter of interpretation. However, with the sword of judgement looming over the head of those who fail to understand the Lord's Supper correctly, one can rightly lament that Paul did not provide a more extensive analysis on the meaning of the words he had received from the Lord. The reason for it could be that there was general consensus on the meaning and that 1 Corinthians 11 in fact addresses another problem, namely that actions speak loader than words.

The critical importance of table fellowship and the symbolic message that actions have - in particular to the world cannot be underestimated. ${ }^{12}$ Praise for adhering to certain custom-defined lines (for the sake of the Gospel) in 1 Corinthians 11:2-16 is followed in verses $17-34$ by criticism for marking lines that should have been obliterated altogether.

Malina and Pilch (2006:105) advocate that the confusion arose in Corinth based on the failure to distinguish between domestic gatherings and public ones. Are the gatherings of the Jesus followers like that of a household or a nonhousehold, even if held in a household setting? Customary behaviours within a kinship setting (husbands and wives, brothers and sisters at home) are quite different to those in the public sphere. There was, for example, no egalitarian public dining. It was status-specific dining, with guests placed in different rooms, their status in society being displayed and confirmed by the quality of food received. ${ }^{13}$ However, in a group professing unity in Christ by his vicarious death for all, any table fellowship that would

11.This is the majority view of confessional Lutherans; see in particular Sasse (1966:115-120; 2014:183-202).

12.The latter is captured in verse 26 , that partaking in the Lord's Supper is a 'proclamation' of his death. This proclamation might be construed as a personal testimony, but it also testifies to the world that through Jesus' death the power of sin have been defeated and those enslaved by sin have now been rescued and united.

13.This account from Pliny the Younger, Letters II, 6, LCL 109-113, quoted by Malina and Pilch (2006) is informative: 'It would be a long story ... were I to recount ... [when] supped lately with a person, who in his own opinion lives in splendor ... Some very elegant dishes were served up to himself and a few more of the company; while those which were placed before the rest were cheap and paltry. He apportioned in small flagons three different sorts of wine; but you are not to suppose it was that the guests might take their choice: on the contrary, that they might not choose at all. One was for himself and me, the next for his friends of a lower order ...; and the third for his own freed men and mine. One who sat next to me took notice of this, and asked me if I approved of it. "Not at all", I told him. "Pray, then", said he, "what then is your method on such occasions?" "Mine", I returned, "is to give all my company is your method on such occasions?" "Mine", I returned, "is to give all my company the same fare; for when I make an invitation, it is to sup not to be censoring. Every man whom I have placed on an equality with myself by admitting him to my table, treat as an equal in all particulars". "Even freed-men?" he asked. "Even them", I said "for on those occasions I regard them not as freed-men, but boon companions". "This must put you to great expense", says he. I assured him not at all; and on his asking how that could be, I said, "Why you must know my freed-men do not drink the same wine I do - but I drink what they do"' (pp. 109-110). exhibit a form of 'censoring' would defy the very purpose and meaning of the Lord's Supper. Therefore, it is highly probable that Paul's focus is first and foremost on social cohesion, albeit against the backdrop of Christ giving his body and blood and thereby inaugurating the new convent of 'mercy'.

It is also striking that despite the warning of judgement on those who take the Lord's Supper in an unworthy manner, 1 Corinthians 11:17-34 (as all meal scenes) remains 'openended'. Paul does not exclude the rich by 'apostolic decree' from sharing in the Lord's Supper. But he does exhort 'selfexamination' (1 Cor 11:24). It is the 'Lord' who judges and disciplines (1 Cor 11:31-32).

That church fellowship is altar fellowship (and vice versa) is a faith assertion that largely defines the identity of confessional Lutherans. The statement in itself carries value, but there should be greater awareness of the unintended consequences.

The intent of the confessional Lutheran forefathers is clear, namely to remain true to Scripture and not to lose the treasure of receiving Christ's redemptive body and blood in the Lord's Supper. However, in practice, it has led to a form of censoring and a division at the Lord's Supper, not necessarily to prevent unworthy participants in receiving the Lord's Supper, but to uphold confessional boundaries and identities. In his Small Catechism (SC), Martin Luther himself asserted that worthiness is determined by faith (alone) - faith in the words 'Given ... and shed for you for the forgiveness of sins' (Concordia 2005:343). Luther appeals to the 'heart' to trust the words of Christ, not the ratio. In contrast to other reformers who engaged in extensive speculations regarding the manner of Christ's presence (that is, to obtain a plausible explanation), the AC (X) resists answering the 'what' of the Lord's Supper, encouraging faith in the words of institution. The understanding was that the sacraments, including the Lord's Supper, were given to the Church of Christ intended for sinners to 'awaken and confirm faith in those who use them' (AC XIII) (Concordia 2005:38).

With the Book of Concord Confessional Lutherans have always rejected the accusation that they regard themselves as the only Church of Christ, stressing that condemnations are directed against godless doctrines and the fanatical opinion of stubborn and blasphemous teachers (and not at persons who err because of a certain simplicity of mind) (cf. Concordia 2005:9; see also Sasse 2014:195). However, if these condemnations lead to exclusions at the Lord's Supper of all who belong to a particular church other than with those with whom church fellowship has been established, then assertions that the Church of Christ is also found in such churches sound hollow. Actions speak louder than words. ${ }^{14}$

14.This is clearly the case with intermarriages between members of different denominations. In South Africa, a high percentage of primarily German-speaking FELSISA members marry a partner from another Lutheran Church with whom no Church Fellowship (as agreement in all doctrines of faith) has been established and Church Fellowship (as agreement in all doctrines of faith) has been established and
vice versa. Should both choose to join the same church, the (unintended) consequence is that one of them may (almost) never share the Lord's Supper with 
Confessional Lutherans need to reconsider whether the intent that their forefathers had is still being achieved through what has become known as the practice of 'closed communion'. If indeed the intent was to speak a clear confession and to safeguard against false or ambiguous teachings in other churches, to which these Christians belong, does Scripture - particularly in the light of Jesus' actions demand a break in table fellowship, or can it be achieved by other means? 1 Corinthians 11:17-31 points the way. False practices are countered no by reverting to a break in table fellowship, but by teaching and speaking a clear testimony (in the ever-continuing endeavour to understand the word's that Paul had received from the Lord better). ${ }^{15}$ This leads to self-examination among those seeking the gift of the sacrament and wishing to partake in the Lord's Supper. God himself, who examines the heart, is the judge. The focus for those who hold the office of the ministry is on 'apostolic teaching' that drives Christ home.

This does not exempt the ordained minister from his Godgiven responsibilities to counter false teachings (that do not drive Christ home), but creates greater awareness not only of the pitfalls of false teachings in other churches but also shameful practices within the own church, as was the case in Corinth. Also the FELSISA serves as an example that a proper understanding of the Lord's Supper does not safeguard against sinful divisions. Although not officially, some FELSISA members have for many years resisted Africans from a partner church, with whom church fellowship had been established, from attending 'their' church services and celebrating the Lord's Supper with them. There is no example in the FELSISA of exercising church discipline against such members. Such actions, as indeed those in Corinth, render all talk of teaching the Gospel purely and administering the sacraments correctly (AC VII) hollow - without denying that even in such a fallible church as the FELSISA, there is Church of Christ. ${ }^{16}$

\section{Conclusion}

This article does not resolve the divisions of the Church, nor will Luther's principle was Christum treibet provide all

\section{(footnote 14 continues...)}

his or her family members again. Some may accede, but often those (ironically for whom the Lord's Supper has always been a tangible act of Christ's unmerited grace for all) will be driven away to the very church that explicitly or in most cases implicitly through fellowship with other church bodies are seen to condone false teachings. Others may have no choice as they have moved to an area where there is no (confessional) Lutheran church at all. Then there are also those who join the FELSISA through marriage or for other reasons, who have - as a result of the clear teaching - experienced the awaking and confirmation of their faith.

15.Contra the Leuenberg Agreement, where the acceptance of differing confessions for the sake of unity can lead to no (clear) confession being spoken at all.

16.Recently (in 2012) the FELSISA amended its constitution to highlight the dua responsibility of (1) the pastor and the congregation and (2) that of guests wishing to attend the Lord's Supper. It is the responsibility of the former, both through clear and unambiguous teaching and a life of reconciliation, to confess the presence and the salvific gift of Christ in the Lord's Supper, and it is the responsibility of the latter, based on the teaching and confession spoken, to examine themselves. If a guest attends, either after speaking first to the pastor whose is encouraged to assist the guest 'in the true understanding and blessed participation of this Sacrament', guest 'in the true understanding and blessed participation of this Sacrament', or when moved by the Spirit through the preaching and the teaching in the divine service (as God's Anrede), it is a moment of joy and celebration. Although this is not the purpose of this practice, it has, in particular in a missional situation (o unexpected guests arriving), led to full membership of those who received the Lord's Supper and were subsequently guided towards a deeper understanding of this sacrament. Constantly raising guilt feelings that God's Law or a church regulation has been transgressed has the opposite effect. answers. But it places the focus on the Christ event, a clear teaching of this event, and proposes a hermeneutic of conversation, characterised by 'a willingness to suspect and a willingness to listen' (Ricoeur 1970:27). This is something I learned at this Faculty of Theology. The faculty has indeed become a gateway to a more inclusive form of practicing theology. Divisions are not seen as barriers, but opportunities to engage, with the Lord's Supper serving as a reminder of God's unifying mercy that transcends all understanding.

\section{Acknowledgements Competing interests}

The author declares that he has no financial or personal relationships which may have inappropriately influenced him in writing this article.

\section{References}

Assendorf, U. \& Künneth, F.W. (eds.), 1974, Leuenberg - Kondordie oder Diskordie?, Verlag Die Spur GMbH \& Co, Christliche Buchhandel KG Berlin und SchleswigHolstein, Die Spur.

Concordia, 2005, P.T. McCain, E.Z. Engelbrecht, R.C. Baker \& G.E. Veith (eds.), The Lutheran Confessions: A reader's editions of the Book of Concord, 2005, 2006, 2nd edn., Concordia Publishing House, Saint Louis, MI.

Dreyer, Y., Zeindler, M., Case-Winters, A., Sadananda, R. \& Weinrich, M., 2013, 'Sola Scriptura: Hindrance or catalyst for church unity?', HTS Teologiese Studies/ Theological Studies 69(1), Art. \#2000, 1-8. https://doi.org/10.4102/hts. v69i1.2000

Heil, J.P, 1990, The Meal Scenes in Luke-Acts: An Audience-Orientated Approach, Society of Biblical Literature, Atlanta, GA.

Heussi, K., 1981, Kompendium der Kirchengeschichte, J.C.B. Mohr (Paul Siebeck), Tübingen.

Horwitz, C., 1964, Evangelisch-Lutherische Freikirchen: Was sie wollen. Wie sie wurden, Missionshandlung, Hermannsburg.

Klän, W. \& da Silva, G. (eds.), 2012, Die Leuenberger Konkordia im innerlutheirschen Streit: Internationale Perspektiven aus drei Konfessionen, Edition Ruprecht, Göttingen.

Kleinig, J., 2002, 'Oratio, Meditatio, Tentation', Concordia Theological Quarterly July, 255-266.

Luther's Works, 1966, CD-ROM (Logos Bible Software), J.J. Pelikan (ed.), Concordia Publishing House, Saint Louis, MI.

Leuenberg Agreement, 1973, viewed 03 January 2017, from http://www.leuenberg. net/leuenberg-agreement

Malina, B.J., 2003, The New Testament World: Insights from Cultural Anthropology, rev. edn., Westminster/John Knox, Louisville, KY.

Malina, B.J. \& Pilch, J.J., 2006, Social-science commentary on the letters of Paul, Fortress Press, Minneapolis, MN

Maurer, W., 1970, 'Luther's Verständnis des neutestamentlichen Kanons', in W. Kohls \& G. Müller (eds.), Kirche und Geschichte: Gesammelte Aufsätze, Luhter und das evangelische Verständnis, vol. 1,pp. 134-158, Vandenhoek \& Ruprecht, Göttingen.

Nafzger, S.H., 2007, 'The Lutheran understanding of church fellowship and its practice with ecclesiastical accountability: A Missouri Synod perspective', in W. Klän (ed.), Lutherische Identität in kirchlicher Verbindlichkeit: Erwägungen zum Weg lutherischer Kirchen in Europa nach der Millenniumswende, pp. 61-87, Edition Ruprecht, Göttingen.

Neyrey, J.H., 1991, 'The symbolic universe of Luke-Acts: "They turn the world upside down"', in J.H. Neyrey (ed.), The social world of Luke-Acts: Models of interpretation, Henrickson, Peabody, MA.

Ricoeur, P, 1970, Freud and philosophy: An essay on interpretation, transl. D. Savage, Yale University Press, New Haven, CT, p. 27; quoted in Dreyer, Y., Zeindler, M. Case-Winters, A. Sadananda, R. \& Weinrich, M., 2013, 'Sola Scriptura: Hindrance Case-Winters, A., Sadananda, R. \& Weinrich, M., 2013, 'Sola Scriptura: Hindrance
or catalyst for church unity?', HTS Teologiese Studies/Theological Studies 69(1), or catalyst for church unity?', HTS Teologiese Studies/Th
Art. \#2000, 1-8. https://doi.org/10.4102/hts.v69i1.2000

Sasse, H., 1966, In Statu confessiones. Gesammelte Aufsätze von Hermann Sasse, F.W. Hopf (ed.), Lutherisches Verlagshaus, Berlin.

Sasse, H., 2014, 'Altar fellowship, church fellowship, and ecclesiastical federation', in M.C. Harrison (ed.), Letters to Lutheran Pastors, vol. II, 1951-1956, pp. 183-204, Concordia Publishing House, Saint Louis, MI.

Thomson, M., 2005, A sure ground on which to stand: The revelation of authority and interpretive method in Luther's approach to scripture, Paternoster.

Van Aarde, A.G., 2001, 'The "cause of Jesus" (Sache Jesu) as the Canon behind the Canon', HTS Theologiese Studies/Theological Studies 57, 148-171. 